FOLIA HISTORICA CRACOVIENSIA, 21: 2015, S. 79-102

DOI: http://dx.doi.org/10.15633/fhc.1731

\title{
Józef Marecki
}

Uniwersytet Papieski Jana Pawła il w Krakowie

\section{Uczeni w habity przyobleczeni}

W 1766 roku nakładem Michała Grölla ${ }^{1}$ ukazał się w Warszawie przekład dzieła Fryderyka Augusta Schmidta, któremu nadano tytuł Dzieje Krolestwa Polskiego krotko lat porzadkiem opisane, na język Polski przełożóne, poprawione i przydatkiem panowania Augusta III pomnożone.

Friedrich August von Schmid (1734-1807) był saskim urzędnikiem, który podczas pobytu w Warszawie został zachęcony przez Józefa Andrzeja Załuskiego i jego bibliotekarza Jana Daniela Janockiego do zajęcia się badaniami nad historią Polski na podstawie zbiorów Biblioteki Załuskich. Efektem był krótki wykład dziejów Polski opublikowany w Saksonii w języku francuskim pod tytułem Abrégé chronologique de l'histoire de Pologne w 1763 roku. W znacznej mierze wykorzystał prace Gotfryda B. Lengnicha ${ }^{2}$, jednak nadał swojej książce układ chronologiczny i tabelaryczny, nadto uwydatnił osiągnięcia kulturalne i naukowe kraju. Tłumaczenia dokonał jezuita Jan Chrzciciel Albertandi³. Książka

${ }^{1}$ Michał Gröll - także Grell, Groel, Grell (1722-1798) - kształcił się w rodzinnej Norymberdze, księgarz w Dreźnie (1756-1768) i równocześnie w Warszawie (od 1759), wydawca „Warszawskich Extraordynaryjnych Tygodniowych Wiadomości” (1759-1763), założyciel warszawskiej Drukarni Narodowej. Zob. A. Pawiński, Michał Gröll, obrazek na tle epoki Stanisławowskiej, Kraków 1896; M. Voigt, Michael Gröll (1722-1798) als polnischer Buchhändler und Verleger der Aufklärung, Nürnberg 1992; D. Sierocka, Die Innovationskraft im Werk Michael Grölls, Posen 1993.

${ }^{2}$ Wł. Gottfried Lengnich (1686-1774) - kształcił się w rodzinnym Gdańsku, Gniewie (w polskiej szkole) i Halle, gdzie uzyskał doktorat z prawa. Po powrocie do Gdańska pracował jako nauczyciel gimnazjalny i prywatny nauczyciel synów Stanisława Poniatowskiego, syndyk miasta Gdańska, prawnik i historyk - zajmował się m.in. dziejami ziem polskich i pruskich, a zwłaszcza Gdańska. Autor licznych dzieł z zakresu historii, edytorstwa źródeł i prawa. Zob. F. X. von Wegele, Lengnich Gottfried, [w:] Allgemeine Deutsche Biographie, Bd. 18, Leipzig 1883, s. 255-257; W. Zientara, Gottfried Lengnich. Ein Danziger Historiker in der Zeit der Aufklärung, Toruń 1995.

${ }^{3}$ Jan Chrzciciel Albertrandi (1731-1808) - jezuita, poeta, publicysta, historyk, źródłoznawca i tłumacz. Współzałożyciel czasopisma „Monitor”, bibliotekarz u Załuskich. Po opuszczeniu Towarzystwa Jezusowego (1767) pozostawał na usługach króla Stanisława Augusta Poniatowskiego. Aktywnie uczestniczył w działalności Towarzystwa do Ksiąg Elementarnych oraz w Towarzystwie Przyjaciół Nauk w Warszawie. W okresie powstania kościuszkowskiego opowiadał się po stronie 
była wykorzystywana jako podręcznik w szkołach Komisji Edukacji Narodowej, przetłumaczona została także na język niemiecki i rosyjski.

Należy dodać, że dzieło Schmidta w języku polskim było wydawane dwukrotnie: pierwszy raz w 1766 roku w Warszawie oraz w wersji znacznie poszerzonej w 1846 roku we Lwowie. Pierwszego wydania nie znał Karol Estreicher. W Bibliografii XIX wieku wymienił jedynie edycję z 1846 roku oraz francuską z błędną datą 1766 (powinno być 1763 ) i niemiecką z 1768 roku$^{4}$.

Jak zaznaczono w tytule publikacja opisywała dzieje Królestwa Polskiego. Dzieło Fryderyka Augusta Schmidta to pierwszy w języku polskim leksykon uczonych polskich, w tym zakonników. To bardzo oryginalne dzieło prozopograficzne, na którym opierali się inni, m.in. karmelita Ignacy Chodynicki ${ }^{5}$ opracowując trzytomowy Dykcyonarz uczonych Polaków, zawierajacy krótkie rysy ich życia, szczególne wiadomości o pismach i krytyczny rozbiór ważniejszych dziet niektórych. Porządkiem alfabetycznym ułożony przez [...] (Lwów 1833). Autor, jak wynika z tekstu opublikowanego $\mathrm{w} 1766$ roku był bardzo krytycznym historykiem. Z rezerwą odnosił się do wcześniejszych publikacji. Wystarczy przytoczyć fragment wstępu: „zmyślone czyny dwóch braci Lecha i Czecha przekładać, także dzieła mniemane ich następców opisywać, byłoby to od bajek poczynać, które acz od większej dziejopisów liczby są przyjęte, jednak nic w sobie pewności nie zawierają".

W zestawieniu autor przedstawił w tabelarycznej formie: władców i czas objęcia rządów, przypadki znakomitsze, małżonki królewskie, ich potomstwo, daty i okoliczności śmierci panujących w opisywanym okresie władców oraz papieży, a od czasów Bolesława Krzywoustego autor wymienia także arcybiskupów gnieźnieńskich, ministrów, wojowników i zamieszcza informację, że ludzi uczonych w tym okresie już Polska miała. Regularny wykaz osób, których nazwał „uczeni i sławą zaszczyceni” wymienia autor począwszy od 1138 roku. Wśród nich są osoby świeckie i duchowne, a wśród tych ostatnich także zakonnicy. Wykaz otwiera Czesław Odrowąż oraz jego brat - Jacek. Określeni zostali jako święci.

Wgłębiając się w lekturę i analizując noty odnoszące się do interesującej nas części należy zauważyć, że w wielu przypadkach autor nie podaje przynależności

zwolenników Moskwy. Sufragan poznański (1796-1798) i warszawski (1798-1808). Zob. A. Schletz, Ks. Jan Albertrandi w latach 1731-1795, „Nasza Przeszłość” 10 (1959), s. 177-208; P. Nitecki, Biskupi Kościoła w Polsce. Słownik biograficzny, Warszawa 1992, s. 18 (tam literatura).

${ }^{4}$ K. Estreicher, Bibliografia polska, t. 4, Kraków 1878, s. 197.

${ }^{5}$ Ignacy Chodynicki (1786-1847) - karmelita dawnej obserwy (karmelita trzewiczkowy), historyk. Zob. J. Wojnarowski, Chodynicki Ignacy, imię chrzestne Kazimierz (1786-1847), [w:] Encyklopedia katolicka [dalej: EK], t. 3, Lublin 1979, k. 206. 
zakonnej, np. dominikanin Stanisław z Krakowa, żyjący w czasach panowania Kazimierza Wielkiego (1333-1370) odpowiada w zestawieniu najprawdopodobniej teologowi określonemu jako „Stanisław z Krakowa Theolog żył około 1350”6. Jednoznacznej identyfikacji nie można jednak dokonać; najprawdopodobniej był to dominikanin, inkwizytor i prowincjał ${ }^{7}$. Podobnie jest w przypadku innych dominikanów: Łukasza Leopolity ${ }^{8}$ i Jan D. Lubienieckiego ${ }^{9}$, jezuitów: Wawrzyńca Bartiliusa ${ }^{10}$ i Jana Chomentowskiego ${ }^{11}$, kanoników laterańskich: Stefana Damalewicza $^{12}$ i Akwlina M. Gorczyńskiego ${ }^{13}$, teatyna Hieronima Clodiniusa (vel Clodinio vel Kłodziński) ${ }^{14}$, cystersów: Bernarda Bodganowicza ${ }^{15}$ i Antoniego Krzesimowskiego $^{16}$, franciszkanina Stanisława działającego w latach panowania Kazimierza $\mathrm{IV}^{17}$ oraz benedyktyna Jędrzeja Wincentego Ustrzyckiego ${ }^{18}$. Natomiast Jakub Radliński wymieniony został tylko jako proboszcz miechowski ${ }^{19}$.

${ }^{6}$ F. A. Schmidt, Dzieje Krolestwa Polskiego krotko lat porzadkiem opisane [...], Warszawa 1766, S. 53.

${ }^{7}$ Por. M. Zdanek, Stanisław z Krakowa, http://ipsb.nina.gov.pl/index.php/a/stanislaw-z-krakowa (10.11.2015).

${ }^{8}$ F. A. Schmidt, Dzieje Krolestwa..., dz. cyt., s. 137.

${ }^{9}$ Zob. F. A. Schmidt, Dzieje Krolestwa..., dz. cyt., s. 281. Por. J. Bartoszewicz, Kościoły Warszawskie rzymsko-katolickie opisane pod względem historycznym, Warszawa 1855, s. 171-201.

${ }^{10}$ Zob. F. A. Schmidt, Dzieje Krolestwa..., dz. cyt., s. 185. Por. C. Falkowski, Bartilius Wawrzyniec, [w:] Polski słownik biograficzny [dalej: PsB], t. 1, Kraków 1935, s. 313; R. Darowski, Wawrzyniec Bartilius SJ (1569-1635). Wybitny Tarnowianin z przełomu XVI i XVII wieku, „Rocznik Tarnowski” 1 (1990), s. 129-132; R. Darowski, Wawrzyniec Bartilius sJ (1569-1635), filozof i teolog, „Bobolanum” 3 (1992), s. 101-111; R. Darowski, Studia z filozofii jezuitów w Polsce w XVII i XVIII wieku, Kraków 1998, s. 61-74; L. Grzebień, Encyklopedia wiedzy o jezuitach na ziemiach Polski i Litwy 1564-1995, Kraków 1996, s. 28.

${ }^{11}$ Zob. F. A. Schmidt, Dzieje Krolestwa..., dz. cyt., s. 185. Por. L. Grzebień, Encyklopedia wiedzy o jezuitach..., dz. cyt., s. 93 (tam bibliografia).

${ }^{12}$ Zob. F. A. Schmidt, Dzieje Krolestwa..., dz. cyt., s. 199. Por. A. A. Chodyński, Stefan Damalewicz. Historyk, przełożony kanoników lateraneńskich w Kaliszu, Poznań 1872.

${ }^{13}$ Zob. F. A. Schmidt, Dzieje Krolestwa..., dz. cyt., s. 279. Por. W. Wicher, Ks. Michał Akwilin Gorczyński (1656-1713), [w:] PSB, t. 13, s. 295nn; M. Madej, Gorczyński Akwilin Michat, [w:] EK, t. 5, Lublin 1989, kol. 1299; M. Pęgier, Konstrukcja kroniki Księdza Stefana Ranatowica CRL (1617-1694) oraz wstępny zarys problematyki, „Saeculum Christianum”, t. 21: 2014, s. 123.

${ }^{14}$ Zob. F. A. Schmidt, Dzieje Krolestwa..., dz. cyt., s. 235.

${ }^{15}$ Zob. F. A. Schmidt, Dzieje Krolestwa..., dz. cyt., s. 277.

${ }^{16}$ Zob. F. A. Schmidt, Dzieje Krolestwa..., dz. cyt., s. 281.

${ }^{17}$ Zob. F. A. Schmidt, Dzieje Krolestwa..., dz. cyt., s. 87.

${ }^{18}$ Zob. F. A. Schmidt, Dzieje Krolestwa..., dz. cyt., s. 281.

${ }^{19}$ Zob. F. A. Schmidt, Dzieje Krolestwa..., dz. cyt., s. 331. 
Podobnie, autor omawianego opracowania nie podaje informacji, że niektórzy z wymienionych uczonych byli kapłanami, np. Mikołaj z Błonia ${ }^{20}$, Mikołaj Husowski ${ }^{21}$, Wojciech Novicampianus ${ }^{22}$, Hieronim Powodowski ${ }^{23}$, Wawrzyniec Jan Rudawski ${ }^{24}$, Szymon Starowolski ${ }^{25}$, Maciej Arcemberski ${ }^{26}$, Marcin Frankowicz ${ }^{27}$, Sebastian Piskorski ${ }^{28}$, Klemens Herka ${ }^{29}$ i Jan Pałaszowski ${ }^{30}$. Przy innych osobach nie zaznaczył, że byli biskupami, np.: Tomasz Zaręba ${ }^{31}$, Jan Romka ${ }^{32}$, Nanker ${ }^{33}$, Piotr Myszkowski ${ }^{34}$ oraz Jerzy Kazimierz Ancuta ${ }^{35}$.

Niektórych osób nie można zidentyfikować, np. „Stanisław z Krakowa Theolog żył około $1350^{\text {"36 }}$ - może to być np. wspomniany wyżej dominikanin. Podobnie F. A. Schmidt wymienia Fabiana Bierkowskiego $(\dagger 1645)^{37}$ - może to dominikanin Fabian Birkowski (†1636), który jest umieszczony w innym miejscu ${ }^{38}$. Na obecnym etapie badań trudno także dokonać jednoznacznej identyfikacji Jana Jaknowicza (zm. 1668), który został określony jako jezuita ${ }^{39}$.

Występują również powtórzenia. Dwukrotnie zamieścił Jana Leopolitę ${ }^{40}$, Bartłomieja Paprockiego ${ }^{41}$, Marcina Śmigleckiego ${ }^{42}$, Stanisława Warszewickiego ${ }^{43}$ oraz Benedykta Zawadzkiego ${ }^{44}$.

${ }^{20}$ Zob. F. A. Schmidt, Dzieje Krolestwa..., dz. cyt., s. 71.

${ }^{21}$ Zob. F. A. Schmidt, Dzieje Krolestwa..., dz. cyt., s. 101.

${ }^{22}$ Zob. F. A. Schmidt, Dzieje Krolestwa..., dz. cyt., s. 139.

${ }^{23}$ Zob. F. A. Schmidt, Dzieje Krolestwa..., dz. cyt., s. 159.

${ }^{24}$ Zob. F. A. Schmidt, Dzieje Krolestwa..., dz. cyt., s. 201.

${ }^{25}$ Zob. F. A. Schmidt, Dzieje Krolestwa..., dz. cyt., s. 201.

${ }^{26}$ Zob. F. A. Schmidt, Dzieje Krolestwa..., dz. cyt., s. 277.

${ }_{27}$ Zob. F. A. Schmidt, Dzieje Krolestwa..., dz. cyt., s. 279.

${ }^{28}$ Zob. F. A. Schmidt, Dzieje Krolestwa..., dz. cyt., s. 281.

${ }^{29}$ Zob. F. A. Schmidt, Dzieje Krolestwa..., dz. cyt., s. 281.

${ }^{30}$ Zob. F. A. Schmidt, Dzieje Krolestwa..., dz. cyt., s. 331.

${ }^{31}$ Zob. F. A. Schmidt, Dzieje Krolestwa..., dz. cyt., s. 49.

${ }^{32}$ Zob. F. A. Schmidt, Dzieje Krolestwa..., dz. cyt., s. 49.

${ }^{33}$ Zob. F. A. Schmidt, Dzieje Krolestwa..., dz. cyt., s. 53.

${ }^{34}$ Zob. F. A. Schmidt, Dzieje Krolestwa..., dz. cyt., s. 139.

${ }^{35}$ Zob. F. A. Schmidt, Dzieje Krolestwa..., dz. cyt., s. 277.

${ }^{36}$ Zob. F. A. Schmidt, Dzieje Krolestwa..., dz. cyt., s. 53.

${ }^{37}$ Zob. F. A. Schmidt, Dzieje Krolestwa..., dz. cyt., s. 185.

${ }^{38}$ Zob. F. A. Schmidt, Dzieje Krolestwa..., dz. cyt., s. 185.

${ }^{39}$ Zob. F. A. Schmidt, Dzieje Krolestwa..., dz. cyt., s. 199.

${ }^{40}$ Zob. F. A. Schmidt, Dzieje Krolestwa..., dz. cyt., s. 113, 137.

${ }^{41}$ Zob. F. A. Schmidt, Dzieje Krolestwa..., dz. cyt., s. 113, 159.

${ }^{42}$ Zob. F. A. Schmidt, Dzieje Krolestwa..., dz. cyt., s. 139, 159.

${ }^{43}$ Zob. F. A. Schmidt, Dzieje Krolestwa..., dz. cyt., s. 125, 159.

${ }^{44}$ Zob. F. A. Schmidt, Dzieje Krolestwa..., dz. cyt., s. 281, 369. 
Wszystkich „uczonych i wsławionych” w omawianym dziele, nie licząc powtórzeń, umieszczono 383, z czego: 1. świeckich - 158 oraz 2. duchownych i zakonnych - 225 - w tym: a. biskupów 29, którzy nie byli zakonnikami, b. duchownych różnych wyznań 35 (oprócz duchownych katolickich także rabina, dwóch pastorów protestanckich, ministra braci polskich oraz duchownego katolickiego, który przeszedł na protestantyzm, oraz c. zakonników 161. Wśród osób świeckich dominują mężczyźni, a wśród uczonych kobiet F. A. Schmidt wymienił Rebekę, córkę rabina Mejera Tiktinera ${ }^{45}$ i Franciszkę Urszulę Radziwiłłową ${ }^{46}$.

Wśród zakonników znaczącą grupę stanowią jezuici - 98. Na drugim miejscu należy wymienić dominikanów - 25. Oprócz wyżej wymienionych w wykazie znajdują się (w porządku alfabetycznym): augustianie - 2, bazylianin - 1, benedyktyni - 3, bożogrobiec - 1, bracia mniejsi - 4, cystersi - 5 (w tym biskup), franciszkanie konwentualni - 4, kanonicy regularni (laterańscy) - 2, kartuz - 1, obserwanci-bernardyni - 5, paulini - 2, pijarzy - 5, teatyn - 1 .

W czasach Bolesława Wstydliwego sprawującego władzę w latach 1227-1270 [s. 32-39] F. A. Schmidt z grona zakonników wymienił cystersa Wincentego Kadłubka (1150/116o-1223) $)^{47}$ - wcześniej biskupa krakowskiego, autora Kroniki polskiej oraz trzech dominikanów: historyka i kanonistę bpa Marcina Strzempskiego (zm. 1279) ${ }^{48}$, Czesława (1175/80-1242) i Jacka (1200-1257) ${ }^{49}$ Odrowążów.

W późniejszym okresie, czyli w latach rządów Leszka II (1279-1289), Przemysława (1289-1296), Wacława (1300-1396), Władysława I Łokietka (1306-1333) w zestawieniu występuje jedynie dominikański kaznodzieja i autor kazań Peregryn z Opola (ok. 1260-ok. 1333) . $^{51}$

W czasach Kazimierza IV (1444-1492) Schmidt wymienił w gronie sławnych osób kartuza, określając go „Jakub z Klui Kartuz inaczey zwany Justerbuk † [zm.]

${ }^{45}$ Zob. F. A. Schmidt, Dzieje Krolestwa..., dz. cyt., s. 368.

${ }^{46}$ Zob. F. A. Schmidt, Dzieje Krolestwa..., dz. cyt., s. 331.

${ }^{47}$ Zob. B. Kürbis, Mistrz Wincenty (tzw. Kadłubek), [w:] Kronika polska, przeł. i oprac. B. Kürbis, wyd. 2, Wrocław 1996, s. III-CXXXII (Wstęp).

${ }^{48}$ Zob. E. H. Wyczawski, Marcin Polak (Carsulanus, Cartulanus, z Oprawy, Scotus, Strempa, Strepori, Strepus, Strzemski, Strzempski), [w:] Słownik polskich teologów katolickich [dalej: SPTK], t. 3, Warszawa 1982, s. 54-55.

${ }^{49}$ Zob. J. Wyrozumski, Św. Jacek Odrowąż na tle swoich czasów, „Zeszyty Naukowe UJ. Prawo Historia" 1989 z. 89, s. 43-52; A. Witkowska, Jacek Odrowąz, Hiacynt (ok. 120o-1257), [w:] EK, t. 7, Lublin 1997, k. 640-641.

${ }^{50}$ F. A. Schmidt, Dzieje Krolestwa..., dz. cyt., s. 46-49.

${ }^{51}$ Zob. J. Wolny, Peregryn z Opola, [w:] PsB, t. 25, Wrocław 1980, s. 598-602; G. Gieraths, Peregrinus OP, Predigtschriftsteller, [w:] Lexikon für Theologie und Kirche, Bd. 8, Freiburg 1986, k. 270. 
1465 albo $1472 " 2^{22}$. Najprawdopodobniej jest to Jakub z Paradyża (1381-1465) autor około 150 traktatów teologicznych i kazan ${ }^{53}$. Następnie wymienił cystersa Jakuba Polaka, określając go jako teologa żyjącego w 1400 roku ${ }^{54}$ oraz niezidentyfikowanego franciszkanina Stanisława ${ }^{55}$.

W latach panowania Aleksandra IV (1501-1506) ${ }^{56}$ i Zygmunta I (1506-1547) ${ }^{57}$ Schmidt nie uwzględnił żadnych uczonych z grona zakonników.

Kolejni uczeni i sławni zakonnicy pojawiają się - według F. A. Schmidta w czasach Zygmunta Augusta (1548-1572) ${ }^{58}$. Są to dwaj jezuici. Pierwszy - polemista, kaznodzieja, autor dzieł homiletycznych i teologicznych - Stanisław Grodzicki (1541-1613) $)^{59}$, drugi to Kasper Sawicki $(1552-1620)^{60}$. Ostatniego z wymienionych wspomniany autor określił jako sławnego teologa toczącego spory $\mathrm{z}$ innowiercami i pisarza o pseudonimie Kasper Cichocki ${ }^{61}$. Do nich dołączył dominikanina Tomasza Szyczowskiego ${ }^{62}$.

W krótkim okresie panowania króla elekcyjnego Henryka Walezego (1573$1574)^{63}$ omawiany autor wymienił jezuitę Stanisława Warszewickiego (ok. 1530-1591) - rektora akademii wileńskiej, legata papieskiego, tłumacza dzieł religijnych i hagiografa ${ }^{64}$, a w czasach panowania Stefana Batorego $(1575-1586)^{65}$ kolejnego jezuitę - pisarza filozoficznego i logika oraz inicjatora nurtu meta-

${ }^{52}$ Zob. F. A. Schmidt, Dzieje Krolestwa..., dz. cyt., s. 85.

${ }^{53}$ Zob. J. Fijałek, Mistrz Jakub z Paradyża i Uniwersytet Krakowski w okresie Soboru Bazylejskiego, t. 1-2, Kraków 1900; S. Dobrzanowski, Jakub z Paradyża, [w:] sPTK, t. 2, Warszawa 1982, s. 109-119; A. Porębski, Jakub z Paradyża. Poglądy i teksty, Warszawa 1994; J. Stoś, Mistrz Jakub $z$ Paradyża i devotio moderna, Warszawa 1997.

${ }^{54} \mathrm{Na}$ obecnym etapie badań nie można dokonać identyfikacji osoby. Może to być opat jędrzejowski Jakub Odrowąż, pierwszy Polak na tym urzędzie, sprawujący tę funkcję w latach 1394-1405.

${ }^{55}$ Zob. F. A. Schmidt, Dzieje Krolestwa..., dz. cyt., s. 87 (obok zapisu cyfra „2483” - zapewne błędna data śmierci).

${ }^{56}$ Zob. F. A. Schmidt, Dzieje Krolestwa..., dz. cyt., s. 94-97

57 Zob. F. A. Schmidt, Dzieje Krolestwa..., dz. cyt., s. 98-107

${ }^{58}$ Zob. F. A. Schmidt, Dzieje Krolestwa..., dz. cyt., s. 108-121.

${ }^{59}$ Wg F. A. Schmidta „Stanisław Grodziecki Zakonu S. J. żył około 1570. Teolog” (F. A. Schmidt, Dzieje Krolestwa..., dz. cyt., s. 111).

${ }^{60}$ Zob. L. Grzebień, Encyklopedia wiedzy..., dz. cyt., s. 602.

${ }^{61}$ Zob. F. A. Schmidt, Dzieje Krolestwa..., dz. cyt., s. 113.

${ }^{62}$ Zob. F. A. Schmidt, Dzieje Krolestwa..., dz. cyt., s. 113. Na obecnym etapie badań nie można dokonać identyfikacji osoby.

${ }^{63}$ Zob. F. A. Schmidt, Dzieje Krolestwa..., dz. cyt., s. 122-133.

${ }^{64}$ Por. S. Bednarski, Stanisław Warszewicki, Kraków 1939; L. Grzebień, Encyklopedia wiedzy..., dz. cyt., s. 725 (tam literatura).

${ }^{65}$ Zob. F. A. Schmidt, Dzieje Krolestwa..., dz. cyt., s. 135-149. 
fizyki neoscholastycznej w Polsce - Marcina Śmigleckiego, który „żył około r[oku] $1581^{\text {"66 }}$. Ponadto Schmidt wymienił Leopolitę, określając go jako teologa żyjącego w 1580 roku $^{67}$. Nie podał przy jego imieniu ani proweniencji zakonnej ani duchownej. Najprawdopodobniej chodzi o dominikańskiego kaznodzieję i teologa związanego z Akademią Krakowską o imieniu Łukasz, określanego niekiedy „Leopolitą” lub „Lwowczykiem”68.

Znaczną grupę uczonych zakonników zestawił Schmidt w okresie panowania Zygmunta III Wazy (1587-1632) ${ }^{69}$. Wśród nich odnajdujemy jezuitów: spowiednika Zygmunta III, autora prac polemicznych i ascetycznych, kierownika szkół jezuickich i rektora Akademii Wileńskiej Fryderyka Bartscha (1552-1609) ${ }^{70}$, mówcę i kaznodzieję patriotycznego, autora rozpraw polemicznych i ascetycznych Mateusza Bembusa (1567-1645) ${ }^{71}$, Jana Branta (1554-1602) $)^{72}$ - określanego jako „wierszopisa” i muzyka ${ }^{73}$, dalej, teologa Stanisława Grodzickiego $(1541-1613)^{74}$, następnie autora dzieł ascetycznych i polemicznych Mikołaja Łęczyckiego (1574$\left.{ }_{1653}\right)^{75}$ i Marcina Łaskiego (zm. 1615) ${ }^{76}$, Szymona Nikowskiego (ok. 1551-1591) określonego przez Schmidta jako „Nicovius” ${ }^{8}$, Justusa Rabusa (zm. 1612) ${ }^{79}$, ka-

${ }^{66}$ F. A. Schmidt, Dzieje Krolestwa..., dz. cyt., s. 139. Zob. J. J. Jadacki, Sławni Wilnianie. Filozofowie, Wilno 1994, s. 142-149; L. Grzebień, Encyklopedia wiedzy..., dz. cyt., s. 676-677 (tam literatura).

${ }^{67}$ Zob. F. A. Schmidt, Dzieje Krolestwa..., dz. cyt., s. 137. Zapewne chodzi o polemicznego pisarza i filozofa M. Śmigleckiego (1563-1618), którego po raz drugi umieścił w latach panowania Zygmunta III.

${ }^{68}$ Por. J. M. Ossoliński, Wiadomości historyczno-krytyczne do dziejów literatury polskiey o pisarzach polskich, także postronnych, którzy w Polscze albo o Polscze pisali, oraz o ich dziełach..., dz. cyt., Krakow 1819, s. 126-127; F. Siarczyński, Obraz wieku panowania Zygmunta III króla polskiego i szwedzkiego zawierajacy opis osob żyjacych pod jego panowaniem, znamienitych przez swe czyny pokoju i woyny, cnoty lub występki, dzieła piśmienne, zasługi użyteczne i celne sztuki, porządkiem abecadła ułożony przez..., dz. cyt., cz. 1, Lwów 1828, s. 270.

${ }^{69}$ Zob. F. A. Schmidt, Dzieje Krolestwa..., dz. cyt., s. 150-181.

${ }^{70}$ Zob. L. Grzebień, Encyklopedia wiedzy..., dz. cyt., s. 30.

${ }^{71}$ Zob. L. Grzebień, Encyklopedia wiedzy..., dz. cyt., s. 35.

${ }^{72}$ Zob. L. Grzebień, Encyklopedia wiedzy..., dz. cyt., s. 66.

${ }^{73}$ Zob. F. A. Schmidt, Dzieje Krolestwa..., dz. cyt., s. 153 (nazwisko: Brantus).

${ }^{74}$ Zob. K. Drzymała, Ks. Stanisław Grodzicki, Kraków 1973; L. Grzebień, Encyklopedia wiedzy..., dz. cyt., s. 197.

${ }_{75}$ Zob. M. Sopoćko, O wychowaniu duchownem, Wilno 1935; L. Grzebień, Encyklopedia wie$d z y \ldots$, dz. cyt., s. 388 (tam literatura).

${ }^{76} \mathrm{~W}$ dostępnych opracowaniach dotyczących jezuitów osoba ta nie występuje.

77 Zob. L. Grzebień, Encyklopedia wiedzy..., dz. cyt., s. 46o.

${ }^{78}$ Zob. F. A. Schmidt, Dzieje Krolestwa..., dz. cyt., s. 159.

${ }^{79}$ Według pomagał ks. Jakubowi Wujkowi w przekładzie Biblii. Zob. Wiadomość o naystarszym może Psauterzu Polskim [...], [w:] Rocznik Towarzystwa Naukowego, t. 12, Kraków 1827, s. 54. 
znodzieję Mikołaja Rakowskiego (1564/65-1618) ${ }^{80}$, Piotra Skargę (1536-1612) ${ }^{81}$ pisarza teologicznego hagiografa, „kaznodzieję i teologa zawołanego”, Jędrzeja Rudominy'ego (ok. 1595-1632) 83 $^{83}$ misjonarza zmarłego w Chinach i tłumacza, dalej, powtórnie teologa Marcina Śmigleckiego(1563-1618) ${ }^{84}$, następnie - także powtórnie - Stanisława Warszewickiego ${ }^{85}$, tłumacza Pisma Świętego Jakuba

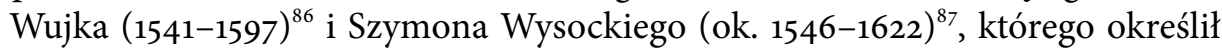
jako tłumacza ksiąg pobożnych ${ }^{88}$.

Oprócz wyżej wymienionych jezuitów w wykazie pojawiło się trzech dominikanów: Szymon Birkowski, teolog i kaznodzieja Seweryn Lubomlius - czyli Lubomlczyk (1532-1612) ${ }^{89}$ oraz teolog i pisarz ascetyczny Mikołaj z Mościsk $(1559-1632)^{90}$.

Kolejna, licząca 15 osób grupa zakonników reprezentujących Zakon Dominikanów (5 osób) oraz Towarzystwo Jezusowe (10 uczonych), pojawia się w czasach Władysława IV (1632-1648) ${ }^{91}$. Są to dominikanie: Abraham Bzowski $(1567-1637)^{92}$ - „pisarz niespracowany, po Baroniuszu roczne dzieje pisał † [zm.] 1537"93, następnie Kamil Jasiński (1573-1649), Piotr Kamiński (†1642), Rajmund Mądrowic (zm. 1641) oraz historyk i heraldyk Szymon Okolski (1580-1653).

Jak zaznaczono wyżej, znacznie większa jest grupa uczonych wywodzących się ze wspólnoty jezuickiej. Są to określani jako teologowie: autor pism ascetycznych Wawrzyniec Bartilius (1569-1635) ${ }^{94}$, przy którym autor nie podał przynależności

Por. H. Witte, Diarium biographicum, in quo scriptores seculi post natum Christum XVIII praecipui, Gedanii 1688 (pod datą 1 IV 1612).

${ }^{80}$ Zob. L. Grzebień, Encyklopedia wiedzy..., dz. cyt., s. 561.

${ }^{81}$ Zob. J. Tazbir, Piotr Skarga, szermierz kontrreformacji, Warszawa 1978; L. Grzebień, Encyklopedia wiedzy..., dz. cyt., s. 619 (tam literatura).

${ }^{82}$ F. A. Schmidt, Dzieje Krolestwa..., dz. cyt., s. 159.

${ }^{83}$ Zob. L. Grzebień, Encyklopedia wiedzy..., dz. cyt., s. 583-584.

${ }^{84}$ Zob. J. J. Jadacki, Sławni Wilnianie. Filozofowie, Wilno 1994, s. 142-149; L. Grzebień, Encyklopedia wiedzy..., dz. cyt., s. 676 (tam literatura).

${ }^{85}$ Zob. przypis 64.

${ }^{86}$ Zob. L. Grzebień, Encyklopedia wiedzy..., dz. cyt., s. 765.

${ }^{87}$ Zob. L. Grzebień, Encyklopedia wiedzy..., dz. cyt., s. 774.

${ }^{88}$ Por. F. A. Schmidt, Dzieje Krolestwa..., dz. cyt., s. 159.

${ }^{89}$ Zob. K. Kanuś, Lubomlczyk Seweryn OP, [w:] EK, t. 11, Lublin 2006, kol. 75-76.

${ }^{90}$ Zob. A. F. Dziuba, Mikołaj z Mościsk. Teolog moralista XVII wieku, Warszawa 1985.

${ }^{91}$ Zob. F. A. Schmidt, Dzieje Krolestwa..., dz. cyt., s. 182-195.

${ }_{92}$ Zob. M. Dynowska, Bzowski Stanisław, [w:] PsB, t. 3, Kraków 1937, s. 186-188.

${ }_{93}$ F. A. Schmidt, Dzieje Krolestwa..., dz. cyt., s. 185 (błędna data śmierci, powinno być 1637).

${ }^{94}$ Zob. L. Grzebień, Encyklopedia wiedzy..., dz. cyt., s. 28. 
zakonnej $^{95}$, pisarz i kaznodzieja Jakub Olszewski (ok. 1585-1634) ${ }^{96}$, kaznodzieja i znawca chronologii Wawrzyniec Susliga (ok. 1580-1641) ${ }^{97}$. Obok nich występują w omawianym tekście architekt i tłumacz Jan Chomentowski [Chomętowski] $(1594-1617)^{98}$ - podany bez przynależności zakonnej ${ }^{99}$, Grzegorz Knapius ${ }^{100}$ (1564-1639) ${ }^{101}$, którego Schmidt określił jako „słownika naywybornieyszego Polskiego, Łacińskiego i Greckiego Autor" ${ }^{102}$, kaznodzieja i pisarz Adam Makowski (1575-1657) ${ }^{103}$, „krasomówca” Jan Rywocki (ok. 1600-1666) ${ }^{104}$, kaznodzieja nadworny Władysława IV, „wierszopis łaciński po starożytnych nayznakomitszy w lirykach"105 Maciej Kazimierz Sarbiewski (1595-1640) ${ }^{106}$, polemista, hagiograf i historyk Fryderyk Szembek $(1575-1644)^{107}$ oraz publicysta i retor Szymon Ugniewski (ok. 1582-1648) ${ }^{108}$.

W latach panowania Jana Kazimierza $(1632-1672)^{109}$ Schmidt wymienił kolejną grupę uczonych zakonników - przedstawicieli wspólnoty benedyktynów, kanoników laterańskich, jezuitów i pijarów. Oczywiście, najliczniejszą - bo liczącą 17 osób grupę stanowią jezuici. Jako pierwszy został wymieniony znany z wielu publikacji o tematyce ascetycznej Kasper Drużbicki $(1590-1662)^{110}$, autor publikacji

${ }^{95}$ Zob. F. A. Schmidt, Dzieje Krolestwa..., dz. cyt., s. 185.

${ }^{96}$ Zob. L. Grzebień, Encyklopedia wiedzy..., dz. cyt., s. 474.

${ }_{97}$ Zob. L. Grzebień, Encyklopedia wiedzy..., dz. cyt., s. 654. F. A. Schmidt (Dzieje Krolestwa..., dz. cyt., s. 189) podal jako datę śmierci rok 1640.

${ }_{98}$ Zob. L. Grzebień, Encyklopedia wiedzy..., dz. cyt., s. 93.

${ }^{99}$ Zob. F. A. Schmidt, Dzieje Krolestwa..., dz. cyt., s. 185.

${ }^{100}$ Określony przez F. A. Schmidta (Dzieje Krolestwa..., s. 185) jako „Knapski”; podał także jako datę śmierci rok 1638 .

${ }^{101}$ Zob. J. Puzynina, Thesaurus Grzegorza Knapiusa, siedemnastowieczny warsztat pracy nad językiem polskim, Wrocław 1961; L. Grzebień, Encyklopedia wiedzy..., dz. cyt., s. 285.

${ }^{102}$ F. A. Schmidt, Dzieje Krolestwa..., dz. cyt., s. 185.

${ }^{103}$ Zob. L. Grzebień, Encyklopedia wiedzy..., dz. cyt., s. 401.

${ }^{104}$ Zob. L. Grzebień, Encyklopedia wiedzy..., dz. cyt., s. 591.

${ }^{105}$ F. A. Schmidt, Dzieje Krolestwa..., dz. cyt., s. 189.

${ }^{106}$ Zob. T. Kaczorowska, Maciej Kazimierz Sarbiewski sJ na Mazowszu, Ciechanów 2005; L. Grzebień, Encyklopedia wiedzy..., dz. cyt., s. 60o-601.

${ }^{107}$ Zob. L. Grzebień, Encyklopedia wiedzy..., dz. cyt., s. 66o. F. A. Schmidt (Dzieje Krolestwa..., dz. cyt., s. 189) podał jako datę śmierci rok 1647.

${ }^{108}$ Zob. L. Grzebień, Encyklopedia wiedzy..., dz. cyt., s. 708. F. A. Schmidt (Dzieje Krolestwa..., dz. cyt., s. 189) podał jako datę śmierci rok 1647; podobnie E. Marylski (Wspomnienie zgonu zasłużonych w narodzie Polaków, Warszawa 1829, s. 218).

${ }^{109}$ Zob. F. A. Schmidt, Dzieje Krolestwa..., dz. cyt., s. 196-235.

${ }^{110}$ Zob. L. Grzebień, Encyklopedia wiedzy..., dz. cyt., s. 133. F. A. Schmidt (Dzieje Krolestwa..., dz. cyt., s. 199) jako datę śmierci podał rok 1660. 
ascetycznych Marcin Hincza (1592-1668) $)^{111}$, Jan Jaknowicz (zm. 1668) ${ }^{112}$, historyk Stanisław Kosiński (ok. 1587-1657) ${ }^{113}$, Wojciech Kwiatkowski (1634-1676) ${ }^{114}$, wykładowca teologii i pisarz Marcin Olszewski (1608-1667) ${ }^{115}$, teoretyk wymowy i pisarz oraz autor panegiryków Bartłomiej Paprocki (1589-1650) ${ }^{116}$, Łukasz Paprocki (ok. 1607-1657) ${ }^{117}$, „krasomówca i wierszopis” ${ }^{118}$ Seweryn Karwat Wokiciewicz (1605-1664) ${ }^{119}$, autor rozpraw polemicznych, historyk, genealog i heraldyk Albert Wijuk Kojałowicz (1607-1677) ${ }^{120}$, autor kazań i utworów panegirycznych Kazimierz Wijuk Koiałowicz $(1617-1674)^{121}$, Jan Kwiatkiewicz $(1629-1703)^{122}-$ przez Schmita określony jako ten, który „dzieie kościelne od W. x. Skargi pisane do czasów swoich przeciągnął" ${ }^{123}$, kaznodzieja Aleksander Lorencowicz $(1605-1675)^{124}$, rektor Akademii Wileńskiej Michał Mazowiecki (1618-1684) ${ }^{125}$, autor panegiryków i scenariuszy przedstawień szkolnych Jędrzej Młodzianowski $(1627-1686)^{126}$, filozof i teolog oraz pisarz ascetyczny Tomasz Młodzianowski $(1622-1686)^{127}$ i Andrzej Zieniewicz $(1608-1687)^{128}$.

Obok jezuitów F. A. Schmidt wymienił kanonika laterańskiego (nie podając proweniencji zakonnej), znanego m.in. z opracowania życiorysu bł. Bogu-

${ }^{111}$ Zob. L. Grzebień, Encyklopedia wiedzy..., dz. cyt., s. 215. F. A. Schmidt, Dzieje Krolestwa..., dz. cyt., s. 199) jako datę śmierci podał rok 1665.

${ }^{112} \mathrm{Na}$ obecnym etapie badań nie można dokonać identyfikacji tej osoby.

${ }_{113}$ Zob. L. Grzebień, Encyklopedia wiedzy..., dz. cyt., s. 307.

${ }^{114}$ Zob. L. Grzebień, Encyklopedia wiedzy..., dz. cyt., s. 351-352.

${ }_{115}$ Zob. L. Grzebień, Encyklopedia wiedzy..., dz. cyt., s. 474.

${ }_{116}$ Zob. L. Grzebień, Encyklopedia wiedzy..., dz. cyt., s. 490.

${ }_{117}$ Zob. L. Grzebień, Encyklopedia wiedzy..., dz. cyt., s. 491.

${ }^{118}$ F. A. Schmidt, Dzieje Krolestwa..., dz. cyt., s. 201.

119 Zob. L. Grzebień, Encyklopedia wiedzy..., dz. cyt., s. 270. Wg F. A. Schmidta (Dzieje Krolestwa..., dz. cyt., s. 201) zmarł w roku 1658; podobnie H. Juszyński (Dykcyonarz poetów polskich, t. 1, Kraków 1820, s. 166) oraz K. Estreicher (Bibliografia polska, Kraków 103, t. 19, s. 161), który podaje rok urodzenia 1612.

${ }^{120}$ Zob. L. Grzebień, Encyklopedia wiedzy..., dz. cyt., s. 291.

${ }^{121}$ Zob. L. Grzebień, Encyklopedia wiedzy..., dz. cyt., s. 290-291.

${ }_{122}$ Zob. L. Grzebień, Encyklopedia wiedzy..., dz. cyt., s. 351.

${ }^{123}$ F. A. Schmidt, Dzieje Krolestwa..., dz. cyt., s. 369.

${ }_{124}$ Zob. L. Grzebień, Encyklopedia wiedzy..., dz. cyt., s. 371.

${ }_{125}$ Zob. L. Grzebień, Encyklopedia wiedzy..., dz. cyt., s. 413.

${ }^{126}$ Zob. L. Grzebień, Encyklopedia wiedzy..., dz. cyt., s. 431.

${ }_{127}$ Zob. F. Greniuk, Tomasz Młodzianowski, teolog moralista, Lublin 1974; L. Grzebień, Encyklopedia wiedzy..., dz. cyt., s. 432.

${ }^{128}$ Zob. L. Grzebień, Encyklopedia wiedzy..., dz. cyt., s. 792. 
miła ${ }^{129}$ - Szczepana Damalewicza (zm. 1673) $)^{130}$, bożogrobca ${ }^{131}$ historyka Samuela Nakielskiego (1584-1652) $)^{132}$ - autora publikacji o dziejach bożogrobców ${ }^{133}$, benedyktyna Stanisława Szczygielskiego (1616-1687) ${ }^{134}$ - m.in. autora historii opactwa benedyktyńskiego w Tyńcu ${ }^{135}$ oraz pijara Benedykta Zawadzkiego (1652-1705) ${ }^{136}$. Ostatni z wymienionych był znanym kaznodzieją i założycielem pierwszej polskiej drukarni w Warszawie ${ }^{137}$.

Czteroletni okres panowania Michała Wiśniowieckiego (1669-1673) ${ }^{138}$ „wsławił się" kolejnymi jezuickimi uczonymi. Autor omawianego opracowania wymienił pisarza i polemistę religijnego Mikołaja Cichowskiego (1598-1669) ${ }^{139}$, Daniela Pawłoskiego $(1627-1673)^{140}$ oraz autora panegiryków Łukasza Stanisława Załuskiego $(1604-1673)^{141}$.

W latach panowania Jana Sobieskiego $(1674-1696)^{142}$, obejmujących łącznie 22 lata, Schmidt wymienił jedynie teatyna ${ }^{143}$ „Hieronima Clodiniusa vel Clodinio vel [Augusta] Kłodzińskiego" (zm. 1670) - autora tekstów mariologicznych, ale

${ }^{129}$ Historia Swiętobliwego Życia Błogosławionego Bogumiła niegdyś arcybiskupa Gnieznieńskiego, a potym przez lat dwanaście w Pustyni Dobrowskiey w dziedzictwie własnym poboznego Eremity. Którego drogi ciała Depozyt wielkiemi cudami y łaskami słynący, w kollegiacie Unieiowskiey złozony iest [...] (Kalisz 1748).

${ }^{130}$ Zob. A. A. Chodyński, Stefan Damalewicz. Historyk, przełożóny kanoników lateraneńskich w Kaliszu, Poznań 1872.

${ }^{131}$ F. A. Schmidt (Dzieje Krolestwa..., dz. cyt., s. 199) określił go jako kanonika regularnego.

${ }_{132}$ Zob. H. E. Wyczawski, Nakielski Andrzej (Samuel), [w:] psB, t. 22, Wrocław 1977, s. 468-469.

${ }^{133}$ De sacra antiquitate et statu ordinis [...] custodum [...] Sepulchri Domini Hierosolymitani (Cracoviae 1625) oraz Miechovia: sive promptuarium antiquitatum monasterii Miechoviensis [...] (Cracoviae 1634).

${ }^{134}$ Zob. I. M. Dacka, „Korona Polska” Kacpra Niesieckiego pomnik staropolskiego piśmiennictwa heraldycznego, Warszawa 2004, s. 74 (tam literatura).

${ }^{135}$ Tinecia sev Historia Monasterii Tinecensis. Ordinis S. Benedicti Primariae inter Polonica Caenobia venerationis (Cracoviae 1668).

${ }^{136}$ F. A. Schmidt sylwetkę Benedykta Zawadzkiego zamieścił dwukrotnie - zob. Dzieje Krolestwa..., dz. cyt., s. 281 (jako datę śmierci podał rok 1706) i s. 368.

${ }_{137}$ Zob. S. Orgelbranda encyklopedia powszechna $z$ ilustracjami i mapami, t. 16, Warszawa 1904, s. 56.

${ }^{138}$ Zob. F. A. Schmidt, Dzieje Krolestwa..., dz. cyt., s. 236-249.

${ }_{139}$ Zob. S. Bednarski, Cichowski (Cichovius) Mikołaj, [w:] PsB, t. 4, Kraków 1938, s. 29; L. Grzebień, Encyklopedia wiedzy..., dz. cyt., s. 99.

${ }^{140}$ Zob. L. Grzebień, Encyklopedia wiedzy..., dz. cyt., s. 495.

${ }^{141}$ Zob. L. Grzebień, Encyklopedia wiedzy..., dz. cyt., s. 780.

${ }^{142}$ Zob. F. A. Schmidt, Dzieje Krolestwa..., dz. cyt., s. 250-273.

${ }^{143}$ F. A. Schmidt (Dzieje Krolestwa..., dz. cyt., s. 253) nie uwzględnił jego proweniencji zakonnej. 
nie podał jego przynależności zakonnej. Obfite w uczonych z kręgów zakonnych były czasy panowania Fryderyka Augusta II (1697-1733) ${ }^{144}$, obejmujące 36 lat. Schmidt wymienił 29 zakonników. Byli to jezuici: rektor Akademii Wileńskiej, pedagog i kaznodzieja Tobiasz Arent (1646-1724) ${ }^{145}$, architekt, autor podręczników do historii oraz modlitewników Jan Drews $(1646-1710)^{146}$, pisarz polemista Jerzy Gengell $(1657-1727)^{147}$, Ignacy Głowacki $(1667-1729)^{148}$, autor poematu opisującego poselstwo Stanisława Chomętowskiego do Turcji pt. Poselstwo wielkie... Stanisława Chomętowskiego (Lwów 1732) Franciszek Gościecki (1668-1729) ${ }^{149}$, pisarz polemiczny Godfryd Tadeusz Hannenberg $(1680-1729)^{150}$, wydawca źródeł Jan Kazimierz Kuszewicz $(1647-1721)^{151}$, następnie filozof, teolog, kanonista i retor Krzysztof Łosiewski (1649-1712) $)^{152}$, autor dzieł teologicznych i ascetycznych Maciej Miłuński (1646-1719) ${ }^{153}$, autor książek ascetycznych Świętosław Zygmunt Niwicki (1640-1702) ${ }^{154}$, autor zbiorów kazań i publikacji ascetycznych Stefan Poniński (1657-1733) ${ }^{155}$, autor kazań pogrzebowych Franciszek Poniński (1661-1714) $)^{156}$, autor anonimowych panegiryków Łukasz Stanisław Słowicki $(1654-1717)^{157}$ i kaznodzieja Antoni Szyrma $(1660-1734)^{158}$.

${ }^{144}$ F. A. Schmidt, Dzieje Krolestwa..., dz. cyt., s. 274-323.

${ }_{145}$ Zob. L. Grzebień, Encyklopedia wiedzy..., dz. cyt., s. 17-18.

${ }^{146}$ Zob. L. Grzebień, Encyklopedia wiedzy..., dz. cyt., s. 131.

${ }^{147}$ Zob. L. Grzebień, Encyklopedia wiedzy..., dz. cyt., s. 178 (tam literatura). F. A. Schmidt

(Dzieje Krolestwa..., dz. cyt., s. 279) podał błędną datę śmierci - rok 1728.

${ }^{148}$ Zob. L. Grzebień, Encyklopedia wiedzy..., dz. cyt., s. 184; F. A. Schmidt (Dzieje Krolestwa..., dz. cyt., s. 279) podał błędną datę śmierci $1728 \mathrm{r}$.

${ }^{149}$ Zob. L. Grzebień, Encyklopedia wiedzy..., dz. cyt., s. 190; F. A. Schmidt (Dzieje Krolestwa..., dz. cyt., s. 279) podał błędną datę śmierci - rok 1727.

${ }^{150}$ Zob. L. Grzebień, Encyklopedia wiedzy..., dz. cyt., s. 209.

${ }^{151}$ Zob. L. Grzebień, Encyklopedia wiedzy..., dz. cyt., s. 349. F. A. Schmidt (Dzieje Krolestwa..., dz. cyt., s. 281) jako datę śmierci podał rok 1719.

${ }^{152}$ Zob. L. Grzebień, Encyklopedia wiedzy..., dz. cyt., s. 390 (tam literatura). F. A. Schmidt (Dzieje Krolestwa..., dz. cyt., s. 281) jako datę śmierci podał rok 1711.

${ }^{153}$ Zob. L. Grzebień, Encyklopedia wiedzy..., dz. cyt., s. 425. F. A. Schmidt (Dzieje Krolestwa..., dz. cyt., s. 281) jako datę śmierci podał rok 1720.

${ }^{154}$ Zob. L. Grzebień, Encyklopedia wiedzy..., dz. cyt., s. 46o. F. A. Schmidt (Dzieje Krolestwa..., dz. cyt., s. 281) jako datę śmierci podał rok 1700.

${ }^{155}$ Zob. L. Grzebień, Encyklopedia wiedzy..., dz. cyt., s. 529.

${ }^{156}$ Zob. L. Grzebień, Encyklopedia wiedzy..., dz. cyt., s. 529.

${ }^{157}$ Zob. L. Grzebień, Encyklopedia wiedzy..., dz. cyt., s. 624. F. A. Schmidt (Dzieje Krolestwa..., dz. cyt., s. 281) jako datę śmierci podał rok 1722.

${ }^{158}$ Zob. L. Grzebień, Encyklopedia wiedzy..., dz. cyt., s. 672 (tam literatura). 
Z grona uczonych dominikanów Schmidt wymienił: tłumacza Jana Alana Bardzińskiego (1657-1706) ${ }^{159}$, autor traktatów teologicznych i hagiograficznych Dominika Frydrychowicza $(1647-1718)^{160}$, późniejszego biskupa bakowskiego Jana Damasceńskiego Mikołaja Lubienieckiego (ok. 1651-1714) ${ }^{161}$ oraz Tomasza Szulca. Z pozostałych wspólnot zakonnych Schmidt wyróżnił benedyktynów: Benedykta Buchowskiego (zm. 1720) ${ }^{162}$ i tłumacza oraz poetę Jędrzeja Wincentego Ustrzyckiego (zm. 1710) ${ }^{163}$, dalej, cystersa, którego mylnie zaliczył do benedyktynów i podał błędną datę śmierci (1708), Bernarda Bogdanowicza (1640-1722) - autora rozpraw z zakresu dogmatyki i ascetyki ${ }^{164}$, a także pozostałych cystersów: Malachiasza Marcina Kramskiego $(\dagger 1730)^{165}$, pisarza ascetycznego Antoniego Jędrzeja Krzesimowskiego $(\dagger 1706)^{166}$ - przy którym nie uwzględnił proweniencji zakonnej i Feliksa Symplicjusza Łąckiego $(\dagger 1700)^{167}$. W dalszej części publikacji autor wymienił kanonika regularnego Akwilina Michała Gorczyńskiego (1656-1713) ${ }^{168}$, augustiańskiego teologa Wawrzyńca Czepańskiego (ok. 1659-1724) ${ }^{169}$, zajmującego się poezją i propagowaniem kultu Matki Bożej paulina Dionizego Chełstowskiego

${ }^{159}$ L. Łukaszewicz, Rys dziejów piśmiennictwa polskiego, Kraków 1838, s. 45; J. M. Ossoliński, Wiadomości historyczno-krytyczne..., dz. cyt., s. 193-200.

${ }^{160}$ Zob. R. Świętochowski, Frydrychowicz Dominik, [w:] PSB, t. 7, Kraków-Wrocław 1948-1958, s. 173; W. Murawiec, Frydrychowicz Dominik, [w:] sptк, t. 1, red. H. E. Wyczawski, Warszawa 1981, s. 491-492. Wg F. A. Schmidta (Dzieje Krolestwa..., dz. cyt., s. 279) zmarł w roku 1716.

${ }^{161}$ P. Nitecki, Biskupi Kościoła w Polsce. Słownik biograficzny, Warszawa 1992, s. 126 (tam literatura). Wg F. A. Schmidta (Dzieje Krolestwa..., dz. cyt., s. 281) zmarł w roku 1716; bez proweniencji zakonnej.

${ }^{162}$ Może pomyłka F. A. Schmidta (Dzieje Krolestwa..., dz. cyt., s. 277); w pocz. XVIII wieku żył poeta benedyktyn Piotr (zak. Benigny) Buchowski (zm. 1742) - zob. P. Sczaniecki, Buchowski Piotr, [w:] EK, t. 2, Lublin 1977, kol. 1149.

${ }^{163}$ L. Łukaszewicz, Rys dziejów piśmiennictwa..., dz. cyt., s. 45. Wg F. A. Schmidta (Dzieje Krolestwa..., dz. cyt., s. 281) zmarł w roku 1720. F. A. Schmidt nie podał proweniencji zakonnej.

${ }^{164}$ J. Ostrowski, Bogdanowicz Bernard, [w:] PsB, t. 2, Kraków 1936, s. 189 (tam literatura).

${ }^{165}$ Zob. J. Popławski, Kramski Malachiasz, [w:] Encyklopedia katolicka, t. 9, Lublin 2002, kol. 1197-1198; A. Ciesielski, Dziedzictwo cystersów. Prace wybrane, Kraków 2013, s. 113-121. Wg Schmidta (s. 281) zmarł w 1730 roku, a wg K. Estreichera (Bibliografia polska, t. 9, s. 217) w roku 1780.

${ }^{166}$ Zob. A. Ciesielski, Dziedzictwo cystersów..., dz. cyt., s. 95-112.

${ }^{167}$ Por. K. Górski, Rola kulturalna klasztorów na Pomorzu, „Studia Pelplińskie” 1985, s. 72-73; Wg F. A. Schmidta (Dzieje Krolestwa..., dz. cyt., s. 281): Lacki.

${ }^{168}$ Zob. M. Madej, Gorczyński Akwilin Michał, [w:] Ek, t. 5, kol. 1299. F. A. Schmidt (Dzieje Krolestwa..., dz. cyt., s. 279) podał jako datę śmierci rok 1710.

${ }^{169}$ Zob. M. Daniluk, Czepański Jan Wawrzyniec, [w:] Ek, t. 3, kol. 833; E. Ozorowski, Czepański Wawrzyniec Jan, [w:] sPTK, t. 1, s. 349-350. 
$(1670-1719)^{170}$, franciszkanów konwentualnych: historyka zakonnego Kazimierza Jana Biernackiego (1629-1725) ${ }^{171}$ i Ludwika Elbinga (1670-1727) ${ }^{172}$, a także dwóch pijarów: pisarza i pedagoga Jana Damasceńskiego Kalińskiego $(1664-1726)^{173}$ oraz powtórnie Benedykta Zawadzkiego ${ }^{174}$.

Ostatnim królem polskim, którego w swym opracowaniu wymienił Schmidt, był Fryderyk August III (1733-1763) ${ }^{175}$. W latach jego panowania, na przestrzeni 30 lat, wspomniany autor odnotował kilkunastu uczonych zakonników. Wśród nich byli jezuici: teolog Aleksander Bakanowski $(1682-1755)^{176}$, wykładowca retoryki Józef Boreyko $(1729-1765)^{177}$, wszechstronnie wykształcony Marcin Bystrzycki (1692-1754) $)^{178}$, autor kazań Jan Ciecierski (1721-1760) ${ }^{179}$, historyk i heraldyk Stanisław Czapliński $(1708-1760)^{180}$, mówca i autor panegirykow Fabian Dochtorowicz $(1694-1766)^{181}$,filozof i teolog oraz pisarz Piotr Drews $(1646-1710)^{182}$, Jan Grobel (1710-1762) ${ }^{183}$, pedagog Faustyn Grodzicki (1710 - po $1773)^{184}$, autor panegiryków Rafał Hempel $(1718-1758)^{185}$, autor kazań i tłumacz

${ }_{170}$ Zob. J. Zbudniewek, Chełstowski Dionizy Andrzej, [w:] sP Tк, t. 1, Warszawa 1981, s. 299-301.

${ }^{171}$ K. Rosenbaiger, Biernacki Kazimierz, [w:] PsB, t. 2, Kraków 1936, s. 81; A. Zwiercan, Biernacki Jan, [w:] EK, t. 2, kol. 545; W. Murawiec, Biernacki Kazimierz Jan h. Pomian, [w:] sp tк, t. 1, s. 145; W. Murawiec, Biernacki Kazimierz Jan h. Pomian, [w:] Słownik polskich pisarzy franciszkańskich (bernardyni i franciszkanie ślascy, franciszkanie konwentualni, klaryski oraz Zgromadzenie III reguŁy), red. H. E. Wyczawski, Warszawa 1981, s. 54-55.

${ }^{172}$ Zob. A. Kubit, Elbing Ludwik (1670-1737), [w:] PSB, t. 6, Kraków 1948, s. 223 (zm. 1737); A. Litwornia, Zapomniany vasarysta staropolski o. Ludwik Elbing (1670-1727) ofM, [w:] Artes atque humaniora. Studia Stanislao Mossakowski sexagenario dicata, red. A. Rottermund i inni, Warszawa 1998, s. 299-309.

${ }^{173}$ Zob. J. Koziej, Kaliński Jan Damascen (1664-1726), [w:] EK, t. 8, Lublin 20oo, kol. 391-392. F. A. Schmidt (Dzieje Krolestwa..., dz. cyt., s. 281) jako datę śmierci podał rok 1730.

${ }^{174}$ Zob. przypis 136.

${ }^{175}$ F. A. Schmidt, Dzieje Krolestwa..., dz. cyt., s. 324-368.

${ }^{176}$ Zob. L. Grzebień, Encyklopedia wiedzy..., dz. cyt., s. 24.

177 Zob. L. Grzebień, Encyklopedia wiedzy..., dz. cyt., s. 57.

${ }_{178}$ Zob. L. Grzebień, Encyklopedia wiedzy..., dz. cyt., s. 82.

179 Zob. L. Grzebień, Encyklopedia wiedzy..., dz. cyt., s. 99. F. A. Schmidt (Dzieje Krolestwa..., dz. cyt., s. 327) jako datę śmierci podał rok 1660.

${ }^{180}$ Zob. L. Grzebień, Encyklopedia wiedzy..., dz. cyt., s. 106.

${ }^{181}$ Zob. L. Grzebień, Encyklopedia wiedzy..., dz. cyt., s. 126 (tam bibliografia)

${ }^{182}$ Zob. L. Grzebień, Encyklopedia wiedzy..., dz. cyt., s. 131. F. A. Schmidt (Dzieje Krolestwa..., dz. cyt., s. 327) jako datę śmierci podał rok 1740.

${ }^{183}$ Zob. L. Grzebień, Encyklopedia wiedzy..., dz. cyt., s. 195. Wg F. A. Schmidta (Dzieje Krolestwa..., dz. cyt., s. 329): Grobell.

${ }^{184}$ Zob. L. Grzebień, Encyklopedia wiedzy..., dz. cyt., s. 197.

${ }^{185}$ Zob. L. Grzebień, Encyklopedia wiedzy..., dz. cyt., s. 212. 
Michał Juniewicz (1709-1760 ${ }^{186}$, autor kazań i katechizmów Franciszek Michał Koczorowski (1687-1743) ${ }^{187}$, wybitny kaznodzieja, poeta i tłumacz Michał Kiełłpsz $(1718-1765)^{188}$, Tadeusz Jan Krusiński $(1675-1757)^{189}$, tłumacz i pisarz teologiczny Piotr Kwiatkowski $(1664-1747)^{190}$, autor kazań i tłumacz Ignacy Karol Łaźniewski (1707-1760) ${ }^{191}$, misjonarz obozowy i autor kazań Jan Legucki (1673-1752) $)^{192}$, wykładowca retoryki, pisarz i poeta Bartłomiej Luder (1679$1747)^{193}$, pisarz i filozof Adam Malczewski $(1680-1754)^{194}$, pisarz i poeta Franciszek Maniecki (1676-1747) ${ }^{195}$, tłumacz Antoni Mekoni $(1684-1744)^{196}$, pisarz religijny Adrian Miaskowski $(1657-1737)^{197}$, Antoni Misztołt $(1685-1740)^{198}$, historyk, autor panegiryków i kazań Adam Ignacy Naramowski (1686-1736) ${ }^{199}$, heraldyk Kacper Niesiecki $(1682-1744)^{200}$, autor religijny Andrzej Jerzy Peżarski $(1685-1744)^{201}$, historyk, polemista i pisarz Jan Poszakowski $(1684-1757)^{202}$, tłumacz Stefan (Szczepan) Puzyna (1667-1738) ${ }^{203}$, autor dramatów szkolnych, kazań i poezji Dominik Rudnicki (1676-1739) ${ }^{204}$, filozof Jędrzej Rudzki $(1713-1766)^{205}$,

${ }^{186}$ Zob. L. Grzebień, Encyklopedia wiedzy..., dz. cyt., s. 255.

${ }^{187}$ Zob. L. Grzebień, Encyklopedia wiedzy..., dz. cyt., s. 289

${ }^{188}$ Zob. L. Grzebień, Encyklopedia wiedzy..., dz. cyt., s. 278.

${ }^{189}$ Zob. L. Grzebień, Encyklopedia wiedzy..., dz. cyt., s. 335. Wg F. A. Schmidta (Dzieje Krolestwa..., dz. cyt., s. 329): Judas Krusiński.

${ }^{190}$ Zob. L. Grzebień, Encyklopedia wiedzy..., dz. cyt., s. 351.

${ }^{191}$ Zob. L. Grzebień, Encyklopedia wiedzy..., dz. cyt., s. 386.

${ }^{192}$ Zob. L. Grzebień, Encyklopedia wiedzy..., dz. cyt., s. 358.

${ }^{193}$ Zob. L. Grzebień, Encyklopedia wiedzy..., dz. cyt., s. 377 (tam literatura).

${ }^{194}$ Zob. L. Grzebień, Encyklopedia wiedzy..., dz. cyt., s. 402.

${ }^{195}$ Zob. L. Grzebień, Encyklopedia wiedzy..., dz. cyt., s. 405. F. A. Schmidt (Dzieje Krolestwa..., dz. cyt., s. 331) jako datę śmierci podał rok 1749.

${ }^{196}$ Zob. L. Grzebień, Encyklopedia wiedzy..., dz. cyt., s. 414. F. A. Schmidt (Dzieje Krolestwa..., dz. cyt., s. 331) jako datę śmierci podał rok 1745 .

197 Zob. L. Grzebień, Encyklopedia wiedzy..., dz. cyt., s. 418.

${ }^{198}$ Zob. L. Grzebień, Encyklopedia wiedzy..., dz. cyt., s. 430. Wg F. A. Schmidta (Dzieje Krolestwa..., dz. cyt., s. 331): Misztold.

${ }^{199}$ Zob. L. Grzebień, Encyklopedia wiedzy..., dz. cyt., s. 450.

${ }^{200}$ Zob. L. Grzebień, Encyklopedia wiedzy..., dz. cyt., s. 457. F. A. Schmidt (Dzieje Krolestwa..., dz. cyt., s. 331) jako datę śmierci podał rok 1743 .

${ }^{201}$ Zob. L. Grzebień, Encyklopedia wiedzy..., dz. cyt., s. 502.

${ }^{202}$ Zob. E. Janikowki, Ks. Jan Poszakowski polski apologeta, „Studia Theologia-Varsaviensia” 1978, nr 2, s. 91-109; L. Grzebień, Encyklopedia wiedzy..., dz. cyt., s. 532.

${ }^{203}$ Zob. L. Grzebień, Encyklopedia wiedzy..., dz. cyt., s. 555.

${ }^{204}$ Zob. M. Eustachiewicz, Twórczość Dominika Rudnickiego (1676-1739), Wrocław 1966; L. Grzebień, Encyklopedia wiedzy..., dz. cyt., s. 583.

${ }^{205}$ Zob. L. Grzebień, Encyklopedia wiedzy..., dz. cyt., s. 584. 
kaznodzieja i mówca Wawrzyniec Rydzewski $(1717-1765)^{206}$, filozof Paweł Stryjeński (1699-1753) ${ }^{207}$, teolog, filozof i pisarz ascetyczny Stefan Szczaniecki (1658$1737)^{208}$, autor panegiryków i utworów ascetycznych Kazimierz Wieruszewski $(1682-1744)^{209}$, teolog i dramaturg Ignacy Wilkinowicz $(1690-1757)^{210}$, autor panegiryków i kazań Wojciech Zabielski $(1706-1756)^{211}$, logik i architekt Tomasz Żebrowski (1714-1758) oraz autor zbiorów kazań Jan Zrzelski (1679-1746) ${ }^{212}$.

Z grona dominikanów (17 osób) wymienił: Franciszka Bernicza (†1756), Tomasza Celejewskiego ( $\dagger 1760)$, „dziejopisa” Jozafata Hofmana [wł. Hoffmana] $(\dagger 1756)$, „dziejopisa” Jacka Kliszowskiego (ok. 1702-1762) ${ }^{213}$, pisarza religijnego Felicjana Nowowiejskiego ${ }^{214}$, teologa Wojciecha Ochabowicza $(\dagger 1746)^{215}$ oraz historyka Michał Siejkowskiego (1695-1752) ${ }^{216}$. E dalszej części podał nazwiska trzech pijarów: historyka prawa i filologa Macieja Dogiela $(1715-1760)^{217}$, pedagoga, kaznodzieję i wierszopisa Dymitra Kolę $(1699-1766)^{218}$, pedagoga, historyka i pisarza Idziego Madejskiego ${ }^{219}$. Kolejną grupę zakonników stanowią

${ }^{206}$ Zob. L. Grzebień, Encyklopedia wiedzy..., dz. cyt., s. 588.F. A. Schmidt (Dzieje Krolestwa..., dz. cyt., s. 333) jako datę śmierci podał rok 1766.

${ }^{207}$ Zob. L. Grzebień, Encyklopedia wiedzy..., dz. cyt., s. 649.

${ }^{208}$ Zob. L. Grzebień, Encyklopedia wiedzy..., dz. cyt., s. 608. Wg F. A. Schmidta (Dzieje Krolestwa..., dz. cyt., s. 333): Szczaniecki.

${ }^{209}$ Zob. L. Grzebień, Encyklopedia wiedzy..., dz. cyt., s. 735. F. A. Schmidt (Dzieje Krolestwa..., dz. cyt., s. 333) jako datę śmierci podał rok 1745.

${ }_{210}$ Zob. L. Grzebień, Encyklopedia wiedzy..., dz. cyt., s. 739.

${ }^{211}$ Zob. L. Grzebień, Encyklopedia wiedzy..., dz. cyt., s. 776.

${ }^{212}$ Zob. L. Grzebień, Encyklopedia wiedzy..., dz. cyt., s. 794.

${ }^{213}$ Zob. W. Murawiec, Kliszowski (Klissowski, Kliszewski) Jacek (ok. 1702-1762), [w:] sPTK, t. 2, s. 288-289. Wg Schmidta (s. 329): Kliszewski.

${ }^{214}$ Wg F. A. Schmidta (Dzieje Krolestwa..., dz. cyt., s. 331): Nowowieyski.

${ }^{215}$ Zob. R. Świętochowski, Ochabowicz Wojciech (zm. 1746), [w:] PSB, t. 23, Wrocław 1978, s. $484-485$.

${ }^{216}$ Zob. B. Natoński, Siejkowski (Sieykowski) Michał (ok. 1695-1752), [w:] sPTk, t. 4, red. H. E. Wyczawski, Warszawa 1983, s. 62-64; Z. Mazur, Siejkowski (Sieykowski) Michat (1695-1752), [w:] PsB, t. 36, Warszawa-Kraków 1995, s. 566-567. Wg F. A. Schmidta (Dzieje Krolestwa..., dz. cyt., s. 333): Seykowski; wg K. Estreichera (Bibliografia XIX wieku, t. 4, s. 152): Siejkowski.

${ }^{217}$ Zob. W. Konopczyński, Dogiel Maciej (1715-1760), [w:] PSB, t. 5, Kraków 1939-1946, s. 280-282, J. Buba, Dogiel Dominik, imię zakonne Maciej (1715-1760), [w:] EK, t. 4, Lublin 1983, kol. 6. Wg F. A. Schmidta (Dzieje Krolestwa..., dz. cyt., s. 327): Dogiell.

${ }^{218}$ Zob. E. Rabowicz, Kola (Coola, Kol) Franciszek, imie zakonne Demetriusz (Dymitr) Franciszek od Poczęcia Panny Marii (1699-1766), [w:] PsB, t. 13, Kraków 1967-1968, s. 284-285.

${ }^{219}$ J. Buba, Madejski Józef Kazimierz h. Poraj, imię zakonne Idzi od św. Józefa (1691-1746), [w:] PsB, t. 19, Wrocław 1974, s. 116-117; B. Brzuszek, Madejski (Madeyski) Idzi od św. Józefa, Józef 
bernardyni (5 osób). Są to - określany jako „w prawie kościelnym biegły” ${ }^{220} \mathrm{ka}$ nonista Serafin Gamalski (ok. 1675-1733) ${ }^{221}$, następnie, pisarz religijny i historyk Manswet Grabowski (zm. 1757) ${ }^{222}$, pisarz ascetyczny Gaudenty Pikulski (zm. $1763)^{223}$, hagiograf Maciej Roznerski (ok. 1700-1758) ${ }^{224}$, teolog i pisarz ascetyczny Jan Szysiecki (ok. 1680-1753) 225.

Wśród uczonych Schmidt wymienił także braci mniejszych, określając ich terminem „franciszkan”: autora pism hagiograficznych Hieronima Gruszeckiego (1709-1764), Antoniego Grzybowskiego (zm. 1749), autora poczytnych w XVII wieku publikacji religijnych Feliksa Szyszczyńskiego (ok. 1702-1758) i Gordiana Wąsowskiego. Dopełnieniem powyższych grup uczonych franciszkańskich jest postać franciszkanina konwentualnego teologa, liturgisty i historyka Ludwika Chybińskiego (zm. 1748) $)^{226}$.

Z innych wspólnot zakonnych w opracowaniu Schmidta pojawili się: bazyliański pisarz Ignacy Kulczyński (1707-1747) ${ }^{227}$, paulin Innocenty Pokorski (1656-1734) - kronikarz zakonny, wybitny kaznodzieja, budowniczym kościoła pw. Ducha Świętego w Warszawie i tamże organizator Arcybractwa Jezusa Pię-

Kazimierz (1691-1746), [w:] spтк, t. 3, s. 31-33. Wg F. A. Schmidta (Dzieje Krolestwa..., dz. cyt., s. 331): Madeyski (†1748).

${ }^{220}$ F. A. Schmidt, Dzieje Krolestwa..., dz. cyt., s. 329.

${ }^{221}$ Zob. E. Sokołowski, Gamalski Serafin (zm. 1733), [w:] PSB, t. 7, s. 260-261; W. Murawiec, Gamalski Serafin (ok. 1675-1733), [w:] Słownik polskich pisarzy franciszkańskich..., dz. cyt., s. 138-139; W. Murawiec, Gamalski Serafin (ok. 1675-1733), [w:] sPтк, t. 1, s. 508-509; B. Migdał, Gamalski Serafin (ok. 1675-1733), [w:] EK, t. 5, kol. 846.

${ }^{222}$ Zob. W. Murawiec, Grabowski Manswet (zm. 1757), [w:] Słownik polskich pisarzy franciszkańskich..., dz. cyt., s. 157-158; W. Murawiec, Grabowski Manswet (zm. 1757), [w:] SPT K, t. 1, s. $580-581$.

${ }^{223}$ Zob. H. E. Wyczawski, Pikulski Gaudenty h. Rogala (zm. 1763), [w:] Słownik polskich pisarzy franciszkańskich..., dz. cyt., s. 376-377; H. E. Wyczawski, Pikulski Gaudenty h. Rogala (zm. 1763), [w:] sPTK, t. 1, s. 359-360.

${ }^{224}$ Zob. K. Grudziński, Roznerski Mateusz (ok. 170o-1758), [w:] Słownik polskich pisarzy franciszkańskich..., dz. cyt., s. 419-420.

${ }_{225}$ Zob. K. Kantak, Sylwetki bernardynów poznańskich. Jan Kapistran Szysiecki, „Kronika Miasta Poznania" 8 (1930) nr 1, s. 68-87; H. E. Wyczawski, Szysiecki (Lubawczyk) Jan Kapistran (ok. 1680-1753), [w:] Słownik polskich pisarzy franciszkańskich..., dz. cyt., s. 485-486.

${ }^{226}$ K. Kantak, Chybiński Ludwik, [w:] PSB, t. 4, s. 10; por. J. Bar, Udział Polski w literaturze franciszkańskiej, „Studia Theologica Varsaviensia 1967, nr 5/2, s. 184 (nr 2049-2051); W. Murawiec, Chybiński Ludwik (zm. 1748), [w:] Słownik polskich pisarzy franciszkańskich..., dz. cyt., s. 87; W. Murawiec, Chybiński Ludwik (zm. 1748), [w:] sP TK, t. 1, s. 327-328. F. A. Schmidt (Dzieje Krolestwa..., dz. cyt., s. 277) podał jako datę śmierci rok 1704.

${ }^{227}$ Zob. M. Pidłypczak-Majerowicz, Książka i biblioteka bazyliańska w XVII-XVIII wieku oraz wplyw kasat na stan ich zachowania i opracowania, „Hereditas Monasteriorum” 1 (2012), s. 87. 
ciorańskiego oraz inspirator pierwszej pieszej pielgrzymki z Warszawy na Jasną Górę w $1711 \mathrm{roku}^{228}$, następnie bożogrobiec i proboszcz generalny miechowski, pisarz i historyk - Jakub Paweł Radliński (ok. 1684-1762) ${ }^{229}$ oraz augustianin Mikołaj Wodziński ${ }^{230}$.

Wśród uczonych Polaków i osób na trwałe związanych z Polską - w ocenie F. A. Schmidta - zakonnicy stanowią grupę znaczącą, największą. W charakterystykach wymieniani są jako teologowie, kaznodzieje i krasomówcy, dziejopisarze, historycy, muzycy, pisarze, heraldycy i genealodzy, prawnicy, twórcy słowników łacińskich i greckich, tłumacze Pisma Świętego, poeci (wierszopisarze i rymopisarze), misjonarze w Chinach. Analizując dzieło F. A. Schmidta możemy zauważyć znaczące dysproporcje odnośnie liczebności osób wykształconych w danych środowiskach zakonnych w poszczególnych odstępach czasowych. Co więcej, Autor pracowania - wydaje się, że w miarę obiektywnie - ukazał udział i wkład poszczególnych wspólnot zakonnych oraz konkretnych zakonników w kształtowanie się polskiej myśli naukowej, religijnej, kulturotwórczej i społecznej.

\section{Streszczenie}

Artykuł omawia dzieło Fryderyka Augusta Schmidta, będące pierwszym wydanym w języku polskim leksykonem uczonych polskich. Ukazało się ono w 1766 roku nakładem

${ }^{228}$ Zob. J. Zbudniewek, Człowiek wielkiej wiary i pracowitości. O. Innocenty Pokorski (16561734), „Studia Claromontana” 2 (1982), s. 116-171; J. Zdubniewek, Pokorski (Pokorny) Innocenty Bartłomiej (1657-1734), [w:] sp TK, t. 3, s. 396-397; J. Zdubniewek, Pokorski (pierwotnie Pokorny) Bartłomiej Innocenty (1656-1734), [w:] PSB, t. 27, Wrocław 1983, s. 238-240.

${ }^{229}$ Zob. L. Grzebień, Radliński Jakub Pawet (ok. 1680-1762), [w:] sPтк, t. 3, s. 479-481; J. Kozłowski, Radliński Jakub Pawet (ok. 1684-1762), [w:] PsB, t. 29, Wrocław 1986, s. 708-710.

${ }^{230}$ Por. G. Uth, Szkic historyczno-biograficzny Zakonu Augustiańskiego w Polsce, Kraków 1930, s. 306-307. 
Michała Grölla w Warszawie. Znacznie poszerzona wersja ukazała się we Lwowie w roku 1846, z francuską z błędną datą 1766 (powinno być 1763) i niemiecką z 1768 roku. Regularny wykaz osób, których nazwał „uczeni i sławą zaszczyceni” wymienia autor począwszy od 1138 roku. Wśród nich są osoby świeckie i duchowne, a tych ostatnich także zakonnicy. Właśnie osobom duchownym autor artykuł poświęca szczególną uwagę.

\section{Słowa kluczowe}

Fryderyk August Schmid, historia polski, zakony, leksykon, Warszawa, Lwów

\section{Abstract}

\section{Habit Clad Scholars}

The article discusses a work by Frederic August Schmidt, i.e. the first lexicon of Polish scholars published in the Polish language. The work was issued in 1766 by Michał Gröll in Warsaw. A considerably extended version was released in Lviv in 1846, with an erroneous French date 1766 (correct: 1763) and a German date in 1768. A systematic list of persons which the author refers to as „learned and famous persons” opens with the year 1138. The catalogue includes lay persons and clergymen alike, the latter also including monastic orders. It is the clergy that receives the author's special attention.

\section{Keywords}

Fryderyk August Schmid, history of Poland, orders, lexicon, Warsaw, Lviv 


\section{Bibliografia}

\section{Źródła}

De sacra antiquitate et statu ordinis [...] custodum [...] Sepulchri Domini Hierosolymitani, Cracoviae 1625.

Historia Swiętobliwego Życia Błogosławionego Bogumiła niegdyś arcybiskupa Gnieznieńskiego, a potym przez lat dwanaście w Pustyni Dobrowskiey $w$ dziedzictwie własnym poboznego Eremity. Którego drogi ciała Depozyt wielkiemi cudami y łaskami słynacy, $w$ kollegiacie Unieiowskiey złozony iest [...], Kalisz 1748.

Miechovia: sive promptuarium antiquitatum monasterii Miechoviensis [...], Cracoviae 1634.

Schmidt F. A., Dzieje Krolestwa Polskiego krotko lat porządkiem opisane, na język Polski przełożóne, poprawione i przydatkiem panowania Augusta III pomnożone, Warszawa 1766.

Tinecia sev Historia Monasterii Tinecensis. Ordinis S. Benedicti Primariae inter Polonica Caenobia venerationis, Cracoviae 1668.

Witte H., Diarium biographicum, in quo scriptores seculi post natum Christum XVIII praecipui, Gedanii 1688.

\section{Opracowania}

Bar J., Udział Polski w literaturze franciszkańskiej, „Studia Theologica Varsaviensia” 7 (1967) nr 1, s. 203-295.

Bartoszewicz J., Kościoły Warszawskie rzymsko-katolickie opisane pod względem historycznym, Warszawa 1855, s. 171-201.

Bednarski S., Cichowski (Cichovius) Mikołaj, [w:] Polski słownik biograficzny, t. 4, Kraków 1938, s. 29.

Bednarski S., Stanisław Warszewicki, Kraków 1939.

Brzuszek B., Madejski (Madeyski) Idzi od św. Józefa, Józef Kazimierz (1691-1746), [w:] Słownik polskich teologów katolickich, t. 3, Warszawa 1982, s. 31-33.

Buba J., Dogiel Dominik, imię zakonne Maciej (1715-1760), [w:] Encyklopedia katolicka, t. 4, Lublin 1983, kol. 6.

Buba J., Madejski Józef Kazimierz h. Poraj, imię zakonne Idzi od św. Józefa (1691-1746), [w:] Polski słownik biograficzny, t. 19, Wrocław 1974, s. 116-117.

Chodyński A. A., Stefan Damalewicz. Historyk, przełożony kanoników lateraneńskich w Kaliszu, Poznań 1872.

Chodyński A. A., Stefan Damalewicz. Historyk, przełożóny kanoników lateraneńskich w Kaliszu, Poznań 1872.

Dacka I. M., „Korona Polska” Kacpra Niesieckiego pomnik staropolskiego piśmiennictwa heraldycznego, Warszawa 2004. 
Daniluk M., Czepański Jan Wawrzyniec, [w:] Encyklopedia katolicka, t. 3, kol. 833.

Darowski R., Studia z filozofii jezuitów w Polsce w XVII i XVIII wieku, Kraków 1998, s. 61-74.

Darowski R., Wawrzyniec Bartilius sJ (1569-1635), filozof i teolog, „Bobolanum” 3 (1992), S. 101-111.

Darowski R., Wawrzyniec Bartilius sJ (1569-1635). Wybitny Tarnowianin z przełomu XVI i XVII wieku, „Rocznik Tarnowski” 1 (1990), s. 129-132.

Dobrzanowski S., Jakub z Paradyża, [w:] Słownik polskich teologów katolickich, t. 2, Warszawa 1982, s. 109-119.

Drzymała K., Ks. Stanisław Grodzicki, Kraków 1973.

Dynowska M., Bzowski Stanisław, [w:] Polski słownik biograficzny, t. 3, Kraków 1937, s. $186-188$.

Dziuba A. F., Mikołaj z Mościsk. Teolog moralista XVII wieku, Warszawa 1985.

Estreicher K., Bibliografia polska, t. 4, Kraków 1878.

Eustachiewicz M., Twóczość Dominika Rudnickiego (1676-1739), Wrocław 1966.

Falkowski C., Bartilius Wawrzyniec, [w:] Polski słownik biograficzny, t. 1, Kraków 1935, s. 313. Fijałek J., Mistrz Jakub z Paradyża i Uniwersytet Krakowski w okresie Soboru Bazylejskiego, t. 1-2, Kraków 1900.

Gieraths G., Peregrinus, oP, Predigtschriftsteller, [w:] Lexikon für Theologie und Kirche, Bd. 8, Freiburg 1986, k. 270.

Górski K., Rola kulturalna klasztorów na Pomorzu, „Studia Pelplińskie” 16 (1985), s. 69-71. Greniuk F., Tomasz Młodzianowski, teolog moralista, Lublin 1974.

Grudziński K., Roznerski Mateusz (ok. 170o-1758), [w:] Słownik polskich pisarzy franciszkańskich (bernardyni i franciszkanie ślascy, franciszkanie konwentualni, klaryski oraz Zgromadzenie III reguty), red. H. E. Wyczawski, Warszawa 1981, s. 419-420.

Grzebień L., Encyklopedia wiedzy o jezuitach na ziemiach Polski i Litwy 1564-1995, Kraków 1996.

Grzebień L., Radliński Jakub Paweł (ok. 1680-1762), [w:] Słownik polskich teologów katolickich, t. 3, Warszawa 1982, s. 479-481.

Jadacki J. J., Sławni Wilnianie. Filozofowie, Wilno 1994.

Janikowki E., Ks. Jan Poszakowski polski apologeta, „Studia Theologia-Varsaviensia” 1978 nr 2, s. 91-109.

Juszyński H., Dykcyonarz poetów polskich, t. 1, Kraków 1820.

Kaczorowska T., Maciej Kazimierz Sarbiewski sJ na Mazowszu, Ciechanów 2005.

Kantak K., Sylwetki bernardynów poznańskich. Jan Kapistran Szysiecki, „Kronika Miasta Poznania" 8 (1930) nr 1, s. 68-87.

Kanuś K., Lubomlczyk Seweryn op, [w:] Encyklopedia katolicka, t. 11, Lublin 2006, kol. 75-76. Konopczyński W., Dogiel Maciej (1715-1760), [w:] Polski słownik biograficzny, t. 5, Kraków 1939-1946, s. 280-282. 
Koziej J., Kaliński Jan Damascen (1664-1726), [w:] Encyklopedia katolicka, t. 8, Lublin 2000, kol. 391-392.

Kozłowski J., Radliński Jakub Paweł (ok. 1684-1762), [w:] Polski słownik biograficzny, t. 29, Wrocław 1986, s. 708-710.

Kubit A., Elbing Ludwik (1670-1737), [w:] Polski słownik biograficzny, t. 6, Kraków 1948, s. 223.

Kürbis B., Mistrz Wincenty (tzw. Kadłubek), [w:] Kronika polska, przeł. i oprac. B. Kürbis, wyd. 2, Wrocław 1996, s. III-CXXXII.

Litwornia A., Zapomniany vasarysta staropolski o. Ludwik Elbing (1670-1727) ofM, [w:] Artes atque humaniora. Studia Stanislao Mossakowski sexagenario dicata, red. A. Rottermund i inni, Warszawa 1998, s. 299-309.

Łukaszewicz L., Rys dziejów piśmiennictwa polskiego, Kraków 1838.

Madej M., Gorczyński Akwilin Michat, [w:] Encyklopedia katolicka, t. 5, Lublin 1989, kol. 1299.

Marylski E., Wspomnienie zgonu zasłużonych w narodzie Polaków, Warszawa 1829.

Mazur Z., Siejkowski (Sieykowski) Michał (1695-1752), [w:] Polski słownik biograficzny, t. 36, Warszawa-Kraków 1995, s. 566-567.

Migdał B., Gamalski Serafin (ok. 1675-1733), [w:] Encyklopedia katolicka, t. 5, kol. 846.

Murawiec W., Biernacki Kazimierz Jan h. Pomian, [w:] Słownik polskich teologów katolickich, t. 1, s. 145.

Murawiec W., Biernacki Kazimierz Jan h. Pomian, [w:] Słownik polskich pisarzy franciszkańskich (bernardyni i franciszkanie ślascy, franciszkanie konwentualni, klaryski oraz Zgromadzenie III reguty), red. H. E. Wyczawski, Warszawa 1981, s. 54-55.

Murawiec W., Chybiński Ludwik (zm. 1748), [w:] Słownik polskich teologów katolickich, t. 1, Warszawa 1981, s. 327-328.

Murawiec W., Chybiński Ludwik (zm. 1748), [w:] Słownik polskich pisarzy franciszkańskich (bernardyni i franciszkanie śląscy, franciszkanie konwentualni, klaryski oraz Zgromadzenie III reguty), red. H. E. Wyczawski, Warszawa 1981, s. 87.

Murawiec W., Frydrychowicz Dominik, [w:] Słownik polskich teologów katolickich, t. 1, red. H. E. Wyczawski, Warszawa 1981, s. 491-492.

Murawiec W., Kliszowski (Klissowski, Kliszewski) Jacek (ok. 1702-1762), [w:] Słownik polskich teologów katolickich, t. 2, Warszawa 1982, s. 288-289.

Natoński B., Siejkowski (Sieykowski) Michał (ok. 1695-1752), [w:] Słownik polskich teologów katolickich, t. 4, red. H. E. Wyczawski, Warszawa 1983, s. 62-64.

Nitecki P., Biskupi Kościoła w Polsce. Słownik biograficzny, Warszawa 1992.

Ossoliński J. M., Wiadomości historyczno-krytyczne do dziejów literatury polskiey o pisarzach polskich, także postronnych, którzy w Polscze albo o Polscze pisali, oraz o ich dziełach..., Krakow 1819, s. 126-127. 
Ostrowski J., Bogdanowicz Bernard, [w:] Polski słownik biograficzny, t. 2, Kraków 1936, s. 189.

Ozorowski E., Czepański Wawrzyniec Jan, [w:] Słownik polskich teologów katolickich, t. 1, Warszawa 1981, s. 349-350.

Pawiński A., Michał Gröll, obrazek na tle epoki Stanisławowskiej, Kraków 1896.

Pęgier M., Konstrukcja kroniki Księdza Stefana Ranatowica CRL (1617-1694) oraz wstępny zarys problematyki, „Saeculum Christianum” 21 ( 2014), s. 121-130.

Pidłypczak-Majerowicz M., Książka i biblioteka bazyliańska $w$ XVII-XVIII wieku oraz wplyw kasat na stan ich zachowania i opracowania, „Hereditas Monasteriorum” 1 (2012), s. 85-97.

Popławski J., Kramski Malachiasz, [w:] Encyklopedia katolicka, t. 9, Lublin 2002, kol. 11971198.

Porębski A., Jakub z Paradyża. Poglądy i teksty, Warszawa 1994.

Puzynina J., Thesaurus Grzegorza Knapiusa, siedemnastowieczny warsztat pracy nad jezykiem polskim, Wrocław 1961.

Rabowicz E., Kola (Coola, Kol) Franciszek, imie zakonne Demetriusz (Dymitr) Franciszek od Poczęcia Panny Marii (1699-1766), [w:] Polski słownik biograficzny, t. 13, Kraków 1967-1968, s. 284-285.

Rosenbaiger K., Biernacki Kazimierz, [w:] Polski słownik biograficzny, t. 2, Kraków 1936, s. 81 .

S. Orgelbranda encyklopedia powszechna z ilustracjami i mapami, t. 16, Warszawa 1904.

Schletz A., Ks. Jan Albertrandi w latach 1731-1795, „Nasza Przeszłość” 10 (1959), s. 177-208.

Sczaniecki P., Buchowski Piotr, [w:] Encyklopedia katolicka, t. 2, Lublin 1977, kol. 1149.

Siarczyński F., Obraz wieku panowania Zygmunta III króla polskiego i szwedzkiego zawierający opis osob żyjacych pod jego panowaniem, znamienitych przez swe czyny pokoju $i$ woyny, cnoty lub występki, dzieła piśmienne, zasługi użyteczne i celne sztuki, porząkiem abecadła ułożony przez [...], cz. 1, Lwów 1828.

Sierocka D., Die Innovationskraft im Werk Michael Grölls, Posen 1993.

Sokołowski E., Gamalski Serafin (zm. 1733), [w:] Polski słownik biograficzny, t. 7, KrakówWrocław 1948-1958, s. 260-261.

Sopoćko M., O wychowaniu duchownem, Wilno 1935.

Stoś J., Mistrz Jakub z Paradyża i devotio moderna, Warszawa 1997.

Świętochowski R., Frydrychowicz Dominik, [w:] Polski słownik biograficzny, t. 7, KrakówWrocław 1948-1958, s. 173.

Świętochowski R., Ochabowicz Wojciech (zm. 1746), [w:] Polski słownik biograficzny, t. 23, Wrocław 1978, s. 484-485.

Tazbir J., Piotr Skarga, szermierz kontrreformacji, Warszawa 1978.

Uth G., Szkic historyczno-biograficzny Zakonu Augustiańskiego w Polsce, Kraków 1930. 
Voigt M., Michael Gröll (1722-1798) als polnischer Buchhändler und Verleger der Aufklärung, Nürnberg 1992.

Wegele von F. X., Lengnich Gottfried, [w:] Allgemeine Deutsche Biographie, Bd. 18, Leipzig 1883 , s. $255-257$.

Wiadomość o naystarszym może Psauterzu Polskim [...], [w:] Rocznik Towarzystwa Naukowego, t. 12, Kraków 1827, s. 54.

Wicher W., Ks. Michał Akwilin Gorczyński (1656-1713), [w:] Polski słownik biograficzny, t. 13, Wrocław-Warszawa-Kraków 1967-1968, s. 295nn.

Witkowska A., Jacek Odrowąż, Hiacynt (ok. 1200-1257), [w:] Encyklopedia katolicka, t. 7, Lublin 1997, k. 640-641.

Wojnarowski J., Chodynicki Ignacy, imię chrzestne Kazimierz (1786-1847), [w:] Encyklopedia katolicka, t. 3, Lublin 1979.

Wolny J., Peregryn z Opola, [w:] Polski słownik biograficzny, t. 25, Wrocław 1980, s. 598-602.

Wyczawski E. H., Marcin Polak (Carsulanus, Cartulanus, z Oprawy, Scotus, Strempa, Strepori, Strepus, Strzemski, Strzempski), [w:] Słownik polskich teologów katolickich, t. 3, Warszawa 1982, s. 54-55.

Wyczawski H. E., Nakielski Andrzej (Samuel), [w:] Polski słownik biograficzny, t. 22, Wrocław 1977, s. 468-469.

Wyczawski H. E., Pikulski Gaudenty h. Rogala (zm. 1763), [w:] Słownik polskich pisarzy franciszkańskich (bernardyni i franciszkanie śląscy, franciszkanie konwentualni, klaryski oraz Zgromadzenie III reguły), red. H. E. Wyczawski, Warszawa 1981, s. 376-377.

Wyczawski H. E., Pikulski Gaudenty h. Rogala (zm. 1763), [w:] Słownik polskich teologów katolickich, t. 1, s. 359-360.

Wyrozumski J., Św. Jacek Odrowąż na tle swoich czasów, „Zeszyty Naukowe UJ. Prawo Historia” 1989 z. 89, s. 43-52.

Zbudniewek J., Chełstowski Dionizy Andrzej, [w:] Słownik polskich teologów katolickich, t. 1, Warszawa 1981, s. 299-301.

Zbudniewek J., Człowiek wielkiej wiary i pracowitości. O. Innocenty Pokorski (1656-1734), „Studia Claromontana” 2 (1982), s. 116-171.

Zbudniewek J., Pokorski (pierwotnie Pokorny) Bartłomiej Innocenty (1656-1734), [w:] Polski słownik biograficzny, t. 27, Wrocław 1983, s. 238-240.

Zbudniewek J., Pokorski (Pokorny) Innocenty Bartłomiej (1657-1734), [w:] Słownik polskich teologów katolickich, t. 3, Warszawa 1982, s. 396-397.

Zientara W., Gottfried Lengnich. Ein Danziger Historiker in der Zeit der Aufklärung, Toruń 1995.

Zwiercan A., Biernacki Jan, [w:] Encyklopedia katolicka, t. 2, kol. 545. 